\title{
Placards as a Language of Civil Protest in Nigeria: A Systemic- Functional Analysis of the Fuel Subsidy Crisis
}

\author{
Chris Uchenna Agbedo \\ Department of Linguistics Igbo \& Other Nigerian Languages, University of Nigeria Nsukka Nigeria
}

\begin{abstract}
This paper examines the linguistic messages of the placards, which were displayed during the fuel subsidy removal protests in Nigeria. In this regard, we rely on the central notion of 'stratification' deriving from Halliday's Systemic-Functional Grammar. The data elicited from the online edition of Nigerian newspapers is subjected to analysis following the analytical procedure of context stratum. The results of the analysis indicate an emerging pattern of civil protest in Nigeria driven by the nation's brand of 'Arab Spring', or the 'Occupy Movement,' which interrogates a wide range of socioeconomic and political ills plaguing the Nigerian nation. Specifically, the protests transcended the narrow confines of hardships caused by the fuel subsidy removal to pertinent issues of official corruption, debilitating cost of governance, crash in public expectations of a Jonathan presidency, and recourse to people power-induced revolution. The paper concludes that the fuel subsidy removal protests provided a teachable moment, the invaluable lessons of which need not be lost on the PDP-led administration of President Goodluck Jonathan.
\end{abstract}

Keywords: context, fuel subsidy, linguistic message, Nigeria, placards, systemic-functional grammar

\section{Introduction}

At its very essence, language can be defined as a tool used for the communication of meaning. However, there is much more than simple lexical or grammatical meaning encoded in text. People use language to achieve goals and express ideas. Through language, individuals establish and maintain social identity and relationships. "We use language to talk about our experience of the world, including the worlds in our own minds, to describe events and states and the entities involved in them. We also use language to interact with other people, to establish and maintain relations with them, to influence their behaviour, to express our own viewpoint on things in the world, and to elicit or change theirs," (Thompson, 2004:30). Of the seven functions of language outlined by Halliday (1973), the representational and personal functions are of utmost relevance in this paper. Representational function is the use of language to make statements, convey facts and knowledge, explain, or report to represent reality as the speaker/writer sees it; the personal function is to express emotions, personality, and 'gut-level' reactions. In this paper, we seek to adopt the analytical procedure of SystemicFunctional Grammar (SFG) enunciated by M.A.K. Halliday in analysing the use to which Nigerians put language in expressing their 'gut-level' feelings about the vexed issue of fuel subsidy removal.

The Petroleum Products Prices Regulatory Agency (PPPRA) had on 1 January 2012 announced the upward review of the pump price of Premium Motor Spirit (PMS) from N65 to N141 following the removal of oil subsidy. This was in line with the provisions of the 2012-2015 Medium-Term Fiscal Framework and 2012 Fiscal Strategy paper submitted by President Jonathan to the National Assembly, which proposed full deregulation of the oil industry beginning from the 2012 fiscal year. This fiscal policy elicited stiff opposition from the organised labour (spearheaded by the Nigerian Labour Congress and Trade Union Congress), and a coalition of civil society groups, opposition politicians, and professional associations all of which coalesced into a Joint Action Front that prosecuted a five-day nationwide protest intended to get the government to reverse the fuel subsidy removal and revert to the N65 pump price of PMS. The protest, which lasted from Monday 9 to Friday 13 January, 2012 witnessed the emergence of 'Occupy Nigeria Movement'.

In the course of the fuel subsidy removal protests, Nigerians gave vent to their pent-up feelings about the way their country was being governed. The oil subsidy struggle transcended the narrow confines of petrol price and developed into a full-scale interrogation of the governance process with penetrating questions being asked about the workings of the system. Tensions on the narrow issue of fuel subsidies have unleashed broader popular anger over corruption and inequality. After decades of shattered promises, today's generation have difficulty believing in the Nigerian state as an agent of development. This was easily discernible from the various placards that were boldly displayed during the protest, which spoke volumes about the express wishes of Nigerians as attested to by public affairs analysts. "Those placards contained the wishes of Nigerians. They needed to be studied carefully," (Amuta, 2012). "Occupy Nigeria was a novel experience, which passed a clear message to Nigerian leaders that it is no longer business as usual," (Gabriel, 2012).

In Systemic Functional Grammar, the central notion is 'stratification' such that language is analysed in four strata - context, semantics, lexico-grammar, and phonology-graphology. Of these strata, we shall focus on 
the context, which consists of the field (what is going on), tenor (the social roles and relationships between the participants), and the mode (aspects of the channel of communication). Specifically, the main thrust of analysis is the channel of communication, that is, the protesters' placards and the implicit linguistic messages they were meant to convey.

\section{Framework}

Systemic functional grammar (SFG) or systemic functional linguistics (SFL) is a model of grammar developed by Michael Halliday in the 1960s, which takes a functional approach to grammar, analyzing language as a social-semiotic of communicative meaning-making. Language and interaction are defined by context and this model seeks to show how contextual meaning is expressed in grammar. SFG is 'systemic' in that grammar consists of a series of choices that can be made in order to express ideas; in other words, language represents a system network within which language choices are meaningful in relation to other choices that are suppressed. It is 'functional' in that the systems achieve certain functions which are realized in the lexico-grammar of the language. There are three 'metafunctions' formulated by Halliday (1994) which form the basic foundation on which Systemic Functional Grammar is based.

Metafunctions are broadly-categorized fundamental functions which each concerns a different kind of meaning within grammatical clauses. The 'experiential' metafunction includes the happenings, or the topic, of a text. An analysis from this perspective consists of examining the system of TRANSITIVITY realized as 'processes' in a verb phrase constituent and its associated participants. There are several kinds of processes and participant types which are given different functional labels according to their role in a clause. The four main types of process are material, mental, relational and verbal, which each have assigned participants relating to each other by means of the process. The 'interpersonal' metafunction involves the structure of clausal elements as they manage the interpersonal relationship between speaker and addressee and achieve the communicative purpose of a text. The MOOD realizes this metafunction and elements of modality, tense and polarity are taken into account. The 'textual' metafunction organizes clauses as messages realized by speakers who arrange the ways in which the various groups and phrases in the clause are ordered with the THEME system.

Systemic-Functional Linguistics (SFL) is a theory of language centred on the notion of language function. While SFL accounts for the syntactic structure of language, it places the function of language as central (what language does, and how it does it), in preference to more structural approaches, which place the elements of language and their combinations as central. SFL starts at social context, and looks at how language both acts upon, and is constrained by, this social context. The analysis of context is broken down into field, tenor, and mode, which collectively constitute the 'register' of a text (Halliday, 1985). The field refers to what is happening, the nature of the social interaction taking place, what is it that the participants are engaged in, in which language figures as an essential component. Tenor is concerned with who is taking part; the social roles and relationships of participant, the status and roles of the participants. The mode is the symbolic organization of the text, rhetorical modes (persuasive, expository, didactic, etc); the channel of communication, such as spoken or written, monologic or dialogic, visual contact, computer-mediated communication, telephone, etc.

In this paper, we adopt the 'functional' aspect of SFL, which is concerned with the contextualised and practical uses to which language is put in analysing the linguistic messages of the placards displayed during the fuel subsidy removal protests in Nigeria.

\section{Data Analysis}

As earlier noted, the Systemic-Functional Grammar analyses language in terms of four strata, one of which is the context, and one that is further broken down into field, tenor, and mode. The thrust of analysis is the mode, which is concerned with the symbolic organization of the text, rhetorical modes, and the channel of communication. In this regard, the channel of communication is placards with different inscriptions that mirrored the peculiar mindsets of the protesters and the communicative functions, which they intended the linguistic messages to achieve. Generally, we have categorised a sample of the placards into five based on their thematic unity - fuel subsidy removal, official corruption, crash in public expectations, governance, and revolution. We set out to examine how the protesters maximised the utilitarian communicative value of placards to address these different but related issues that are of grave implications for governance in Nigeria.

\subsection{Fuel subsidy removal}

A major component of the policy fiscal consolidation (2012-2015 Medium Term Fiscal Framework (MTFF) and the Fiscal Strategy Paper (FSP) is government's intent to phase out fuel subsidy, beginning from the 2012 fiscal year. The policy, as President Jonathan claimed in his submission to the National Assembly, "will free up to about N1.2 trillion in savings, part of which can be deployed into providing safety nets for poor segment of the society to ameliorate the effects of subsidy removal." This proposed fiscal policy sustained by stereotypical and tasteless recitation of wonky and threadbare economic arguments of the federal government in 
favour of fuel subsidy removal elicited stiff opposition from a wide segment of the Nigerian society. (See Fig. 1).

Apart from the organised labour that vowed to shut down the country should the government make good its threat, a good number of discerning Nigerians saw fuel subsidy removal as the brainchild of the Bretton Woods Institutions intended as a neocolonial stratagem to teeter the Nigerian economy irredeemably to the enslaving apron-strings of the Euroamerican imperialism. It made little sense to them that ordinary Nigerians should be compelled to subsidise waste, mismanagement, and official corruption that have become the trademark of Nigeria's oil industry, which brought about importation of petroleum products in the first place and the subsidy that goes with such woeful economic system. Perhaps, the whole fuel subsidy debate would have made sense if it formed part of a larger effort by government to keep faith with market-driven economic policies, which would have predisposed it to be more accountable, reduce waste in public expenditure, conduct the business of government in a more sensible and business-like manner. Also, the whole argument would have made even more sense if it formed part of an ideological change in the direction of government policy intended to institutionalise a functional market determined economy in which everyone pays for whatever they want to enjoy be they political officials or private citizens and conversely dismantle an economic system, which compels the poor, hapless innocent masses of Nigerians to subsidise the filthy comfort, hedonistic extravagance and slothful luxuriance of only a tiny elitist minority.

The communication deficit of the Jonathan fuel subsidy removal campaign imposed great debilitating constraints on the administration's propaganda team that compelled it to open a debate that confounded rather than enlightened the Nigerian populace on the tenability of its argument. In failing to explain the kernel of the hysterical chatter about oil subsidy, most of the government apologists were content with anchoring their hollow argument on the fabled existence of a cabal in the oil industry that is carting away billions of petro-dollars from the government in the name of fuel subsidy, without lifting the veil off the dim-light shadows that erected and sustained the shenanigan octopus or even offer a simple definition of this ex-terrestrial creature called fuel subsidy.

Apart from the dubious origin which cloned and vested the strange animal called fuel subsidy with a badge of infernal liability, there was hardly a consensus on facts and figures among advocates of subsidy removal, as they reeled out homologous and conflicting figures. The consensus terminated at the viciously pedestal level of a Machiavellian determination to get hunger and poverty-stricken Nigerians to pay more for petroleum products so that governments can effectively keep outright bankruptcy at bay and get more money to carry on with the tinkering or trial-and-error business of governance in Nigeria. For instance, the governors had a different set of figures from the Federal Government because they wanted a review of the revenue allocation formula in favour of the states and local council areas. The Nigerian National Petroleum Corporation (NNPC) also generated a different set of unverified figures on the basis of which it was alleged to cream off stupendous sums of money from the federation account every month. Perhaps, it was against this background of discordant cacophony and cerebral confusion that firmly hemmed in the misty outlines of the fuel subsidy figment.

The foregoing represents a tight summary of the linguistic messages, which the placards in this category were meant to communicate. In summary, the protesters spoke through their placards: "Jonathan, reverse fuel subsidy removal because that's the only thing we enjoy from the government, we don't want corruption, and we are ready to fight it with the last drop of our blood." Before rounding off this section, it is pertinent to note that as the 'Occupy Nigeria' protest progressed, the debate quickly shifted from the quaint calculus of subsidy removal to more inflammable issues of grave concern. Protests against federal government's decision to end fuel subsidies escalated to include mass discontent at corruption, mass unemployment, and lack of infrastructure. Equally interrogated were the nagging issues of governance quality, heavy cost of governance, and the beleaguered Nigerian federation, which were either quickly addressed decisively through due process or the cavalier and radical path of revolution. In the subsequent sub-sections, we shall address these different but related themes as overtly advertised by the protesters' placards.

\subsection{Corruption}

The placards in this category have corruption as their theme. (See Fig. 2). Every simple sentence has a theme (Brown \& Yule (1983) or what Mathesius (1942) refers to as 'the starting point of the utterance' and a rheme, everything else that follows in the sentence, which consists of 'what the speaker states about or in regard to, the starting point of the utterance. The theme, then, is what speakers / writers use and what Halliday (1967: 212) calls a 'point of departure. From the nature and content of the placards, there exists a wide variety of syntactic forms, which the protesters used to convey the same propositional or cognitive content. Whether it is 'Kill corruption, not Nigerians,' 'tackle corruption and cut cost before removing fuel subsidy' or 'Expose corruption,' the same propositional content is expressed each time. In almost all the cases, the protesters asserted through their placards that corruption is the pivot around which all other national development challenges revolve. Dismantle the ulcerous bugbear and the rest aspects of our national life would be automatically fixed, 
they seemed to be chorusing. They questioned the oil subsidy business, which had become a scandalous patronage system, the beneficiaries of which seemed determined to perpetuate it and truncate the original vision of functional local refining to shield the consumers from the vagaries of international pricing.

Perhaps, the exigency of keying into the popular vision of cutting the nation's corruption monster to size predisposed President Jonathan in his speech on 15 January 2012, to underscore the urgency of addressing pandemic corruption in the NNPC. Before the presidential acknowledgement of official corruption in the oil industry, the Finance Minister and Co-ordinating Minister for the Economy, Dr. Ngozi-Okonjo Iweala had admitted that there may have been some fraud in the payment of N3.655 trillion as subsidy to fuel importers as revealed by the Abbe-led Senate Subsidy Probe Committee., Dr Okonjo-Iweala, said the Federal Government was aware 'there may have been 'mago-mago' (shaddy deals) in the payment of fuel subsidy to major oil marketers. "I am not trying to hold brief for anybody or say that everything is perfect, that there is no magomago inside. But what I am saying is that that money was what people spent to bring in products... So, I am not saying it is perfect, don't get me wrong, what I am saying is that the money is for transacted business...This does not mean that we should allow Nigerians to be cheated, some of that money is genuine," the Minister said, (Oluwasegun \& Anofi, 2011).

The House of Representatives took up the gauntlet of combating corruption in the oil industry when it set up the Farouk Lawan-led Ad hoc committee to probe the subsidy payments made the benefiting companies that had earlier been unveiled by a parallel probe committee of the Senate. Chairman of the House Committee, Mr. Lawan added another twist to the actual cost of subsidy payments in 2011 when he contended that the actual amount was in the region of $\mathrm{N} 2$ trillion. In essence, the linguistic messages intended by a good number of those placards to communicate not only transcended the narrow confines of the fuel subsidy removal debacle but equally exuded an appreciable dose of illocutionary force, which ripple perlocutionary effects of variegated dimensions seared the soul of Nigeria's most lucrative industry - corruption.

\subsection{Crash of public confidence in President Jonathan's administration}

The protesters' placards in this category displayed linguistic messages, which generated awful imageries depicting their loss of confidence in the ability and readiness of Jonathan administration to fulfill its campaign promises to the Nigerian people. Four youth groups vis the Nigerian Youths' League (NYL), National Association of Nigerian Students' (NANS), Association of Writers and Artists against Fuel Subsidy Removal (AWAAFSR) and the National Youth Council of Nigeria (NYCN) have condemned Federal Government's decision to remove fuel subsidy. The groups said by virtue of what government had done, the masses, especially the youths had lost the trust and confidence, which it reposed in it, (Umoren, 2012).

Given this backdrop of 'trust deficit between the government and its people,' the advent of a Jonathan presidency, which rode on the crest of divine providence, represented a huge opportunity for effecting a radical departure from the inglorious past characterised by instrumental leadership. When he was elected president in April 2011 through the instrumentality of an unprecedented pan-Nigerian mandate, President Jonathan was described as "Nigeria's Obama," a leader who would bring positive changes to the oil-rich but poverty-ridden nation. Nigerians believed a divine hand orchestrated his success. After all, his name spoke of his destiny: Goodluck Jonathan. Nigerians desperately wanted to believe in Jonathan's capacity to bring change, essentially because they liked his feline meekness and supple humility and identified with him. Goodluck Jonathan used his humble beginnings as political capital during his election campaign in 2011. In an oft-repeated speech, he said:

In my early days in school I had no shoes, no school bags. I carried my books in my hands but never despaired, no car to take me to school, but I never despaired. There were days I had only one meal, but I never despaired. I walked miles and crossed rivers to school every day, but I never despaired. I didn't have power, didn't have generators, studied with lanterns, but I never despaired. In spite of these, I finished secondary school, attended the University of Port Harcourt, and now hold a doctorate degree. Fellow Nigerians, if I could make it, you too can make it!

Nigerians lapped up this man-of-the-people rhetoric, hence the pan-Nigerian mandate freely expressed at the April 2011 polls.

However, few months after his election and presidential inauguration, Jonathan, had in an ironic twist of fate, become an embattled leader whose popularity had plummeted almost irredeemably. This crash of expectations was clearly evident when angry Nigerians took to the streets during the fuel subsidy crisis carrying his mock coffin and placards calling him 'President Badluck'. His 'no shoes' metaphor became the butt of ludicrous allusions of social media activism. (See Fig. 3). Take note of the tinge of satire implicit in one of such computer-mediated messages, which drenched the social media:

Now available for sale in different sizes: bicycles, camels, horses and donkeys. We can also train you on how not to buy shoes for your wards to school, since there are no functional public schools to attend. Visit our office at No.1 Oil Subsidy Road, Diezani Alison-Madueke Avenue, Goodluck Close, off Okonjo-Iweala 
Street, by Labaran Maku Crescent, Sanusi Lamido District, Abuja. Welcome to the year of transformation from going to school without shoes to residing at Aso Villa.

Also, one of the pictures of the fuel subsidy protests depicted puppetry wherein President Jonathan was cast in the ludicrous mould of a frolicking puppet being pulled from different directions by members of the socalled Economic Management Team. By their dexterous manipulations of the strings, they reconfigured the dancing steps of the puppet to rhyme with the rhythmic and lyrical precisions of their principal choreographers the Bretton Woods Institutions. Ironically, the same choreographers who regales Nigeria as good candidate to swallow its poisoned chalice of free market economic policy hook, line, and sinker, did not consider her candidate, Dr. Okonjo-Iweala, fit enough to head the World bank

Perhaps, it is pertinent to aver that the loss of trust in Jonathan's administration did not happen overnight. Critics claim that his sudden fall from grace drew inspiration from a series of blunders, beginning with his effort, just months after his election, to extend the presidency tenure from four to six years, the inept and clueless response to the grave security challenges posed by the Boko Haram insurgency, his apparent lack of political mettle to combat the ever-thriving corruption industry. The oil subsidy removal was the last straw that ignited the massive loss of confidence in so little time.

\subsection{Quality and cost of governance}

The placards in this category speak volumes of the poor quality and huge cost of governance that has become an albatross around the neck of President Jonathan's administration. (See Fig. 4). This was equally evident in the various press statements released by a number of coalition groups that formed that the 'Occupy Nigeria Movement,'(Akowe, 2012; Ehikioya, 2012). Besides these and other similar statements, a number of placards displayed by the protesters raised objections to the poor quality and high cost of governance in Nigeria. In contemporary Nigeria, the cost of governance encapsulates the huge financial, moral, even reputational cost to Nigeria as a country, and Nigerians as a people, of maintaining (s)elected office holders, appointed officials (including the sundry hangers-on and a coterie of political odd jobbers), and career officials in the three tiers of government in an executive presidential system.

To watchers of the polity, the government is becoming one of the heaviest bureaucracies of all times, piling up over 20 extra-ministerial committees, in addition to the huge number of ministries, departments and agencies (MDAs). At the comparative level, very few countries, match the cost of governance, particularly the cost of general administration in Nigeria. The United States, the largest economy in the world, with a GNP of US\$ 13 tr. per annum, has a federal cabinet not exceeding 20, less than half that of Nigeria. The cost of general administration represents less than $10 \%$ of the federal budget of the US. Unfortunately, bloated bureaucracies do not necessarily translate to good or effective governments. On the contrary, there is overwhelming evidence that the bigger the government, the higher the probability of wasteful spending and large scale public corruption, (Fafowora, 2011).

Perhaps, it was in the light of the foregoing that the Theophilus Danjuma-led Presidential Advisory Committee, PAC, had in January 2011, expressed concern over the increasing cost of governance and advised President Jonathan to reduce the number of ministries, departments and agencies (MDAs). While the initial body language of President Goodluck Jonathan gave the impression that he was favourably disposed to such policy measures that discourage bloated government and wastages, the reverse seems to be the case, some long dreary months into his administration. The uproar associated with many provisions of the 2012 budget, which have generally been termed as wasteful, bloated and unrelated to the felt needs of the majority of Nigerians seem to indicate the clear-cut policy thrust of Jonathan administration.

The Guardian editorial of 11 January, 2012 described the emerging indication that ministries, departments and agencies (MDAs) of the Federal Government will spend a whopping N11.25 billion on foreign trips alone in the 2012 budget as "deplorable, scandalous, and shamefully insensitive to the state of the nation." In December 2011, the Director of Budget, Dr. Bright Okogu, admitted that the federal government's wage bill for 2011 had hit N1.5 trillion, almost a third of the government's annual budget for the year. This was predicted to rise to N1.7 trillion in 2012. If Dr. Okogu was to be believed, it means that personnel costs alone in the federal government will account for 50 percent of recurrent expenditure and 36 percent of the total budget in 2012.

The federal government, apart from its 42 ministries, runs about 400 parastatals. The ministries with the highest numbers are Health, 77; Science and Technology, 40; Education, 41; Agriculture, 44; Power and Steel, 27 agencies. This is in addition to countless number of standing and sitting committees, which seem to indicate that the focus of the authorities hardly reckoned with the crushing cost of governance, (Salaudeen, 2012). The number of committees/task forces that have so far been set up calls to question the sincerity of the administration to genuinely cut down the cost of governance. The question is whether Nigeria needs such an unwieldy and bloated system of governance? The answer can hardly be in the affirmative because the country may not make any headway in any sphere of life if she continues to have such a large government with the 
attendant bureaucratic flatulence that could exert undue pressures on the fast depleting national resources. As the Guardian editorial (Monday, 23 January 2012) puts it, "the horrendous cost of governance is at the heart of the people's disenchantment with the government."

\subsection{People power as precursor of revolution}

A sample of placards in this category depicted a sudden socio-political awakening of Nigerian citizens for participatory democracy, one that predisposed them to appreciate the fact that power belongs to them and that those who hold positions of authority do so on behalf of the people and must of necessity remain accountable to the people. (See Fig. 5). The protests have emboldened ordinary Nigerians and raised new awareness of wasteful expenditure. The fuel subsidy struggle brightened the prospects of a revolution in Nigeria, which implied the exercise of people power for the socio-economic and political advancement of Nigeria. In simple parlance, people power is the mass attempt by non -violent protesters to overthrow despots or a movement for a peaceful regime change. People power is the prerogative of the people to determine who governs them and how they are governed in a society to which they have submitted their sovereign will under a system that is agreeable to them. It could come in the form of open support for the activities of their duly elected representatives or through open condemnation and opposition to their leaders. People power can be perceived as the preponderance of the political will of the people of a nation that can be mobilized against or in support of any cause. It can also be said to be the force of the people's will along a particular course, and it represents the ultimate barometer of resolution on contentious state or national issues, (Mimiko, 2011).

As the nationwide strike declared by the organised labour took off Monday, 9 January 2012, members of civil society organisations, politicians, political activists, actors and musicians declared in resolute terms that the much canvassed revolution had finally commenced. The massive protest rally held at Gani Fawehinmi Park, Ojota, featured 76-year-old politician and political activist, Dr. Tunji Braithwaite, who said the current event in Nigeria showed that the appointed time to rescue the soul of Nigeria from those who held it captive had finally come. "There's something called an appointed time. We are here today on this podium to announce to our children and rulers that the appointed time has arrived. There's no going back. With the power of the Almighty with us, we are taking over our nation and the entire black race and freeing ourselves," Braithwaite said. In his own remarks, Denja Yakub of NLC noted, "If a revolution will solve our problems, why not, what is going on already shows that our people are prepared for a revolution..."

It was little wonder how President Jonathan managed to rally the entire country against himself and stoke the little fires of discontent into a consuming conflagration. Definitely, he grossly underestimated public reaction to the removal of fuel subsidy as a major public policy. Perhaps, his advisers never spared a fleeting thought for the likely political backlash, which fuel subsidy removal (considered from a purely simplistic perspective as a mere technocratic decision) would engender. Moreover, former President Obasanjo increased the prices of petroleum products almost uncountable times during his eight-year rule without igniting any public outrage comparable to the national upheaval of cataclysmic proportion, which greeted the fuel subsidy removal misadventure of 1 January 2012. But unknown to this line of reasoning is the fact that under Obasanjo, there were no facebook, twitter, ipad, ipod, or blackberry as potent tools of mobilisation and razor-edge social media activism. There was neither 'Arab spring' nor 'Occupy movement'. But in contemporary times, it is 'no longer at ease'.

As Richard Spencer of the Telegraph UK wrote, "In the 21st century things will be different. The internet has brought people closer to their leaders. It is they who will determine their futures, not the ambitions and ideologies of their generals." Really, things have changed dramatically over the years and it was Jonathan's great (mis)fortune to be the first Nigerian ruler to embrace the thorny chest of social media-induced resentment. History abound with examples of the withdrawal of the people's support and cooperation, thus leading to loss of credibility and legitimacy of the government, which is the whole essence of the social contract as brilliantly espoused by John Locke. The truth of the matter is that the gear of Nigerian brand of revolution automata has been engaged and only a slight throttle is required for it to go full blast. A revolution is a serious social and security problem that can threaten the very foundation of a country. The onus lies on the government of the day to do everything humanly possible to stymie it.

\section{Lessons Of The Placards}

From the tone and texture of the placards displayed during the fuel subsidy protests, it would be right to say that the protesters, who can be described as the microcosmic representation of the over 140 million Nigerians, have given vent to their pent-up feelings about how the serious business of governance is being prosecuted in their (dear?) country Nigeria by a band of both 'shoe-less' and 'shoe-ful' politicians. Surely, the immediate dangers of the subsidy hullabaloo and 'Occupy Nigeria' movement may have been averted or postponed. Also, the seeming clueless Jonathan government may have been successfully escorted through an extremely precarious policy terrain by the National Assembly, acting in concert with the Governor's Forum and 
the organized labour. Nonetheless, the subsidy protests provided rare teachable moments, the lessons of which the Federal Government can only afford to squander at its own peril.

First, the Federal Government needs to rethink its mechanism of policy-decision and crisis management strategy. The timing of the price increase in the aftermath of a Christmas marred by an unfortunate bomb blast was unfortunate. The choice of January, a time when most people are stone broke after the expenses of the end of the year and are eager to return to work in the midst of school fees and other beginning of the year costs is even more questionable. The Action Congress of Nigeria described the Boko Haram insurgency and the petroleum subsidy removal as a "potent mix that can push the country to the precipice," (Amuta, 2012). The unfolding events provoked questions as whether there were not enough pressure, tension, edginess, heat, restiveness, and restlessness in the land that Mr. President must exacerbate these inflammable indices in an already over-heated polity? In Atalanta in Calydon, the literary work of Algernon Charles Swinburne, Aphrodite, the Greek goddess of love, was asked: "Was there not evil enough, Mother, and anguish on earth, born with man at his birth... that thou must lay on him love?" In the same manner that Aphrodite was accused of adding to man's troubles by imposing love on him, with all the troubles that come with it, so were Nigerians asking President Jonathan whether there was not enough trouble in the country that the fuel subsidy removal must come when it did.

Public support in a democracy is essential to the success of public policy. From the comments of a good number of informed Nigerians, subsidy removal, where it is orderly implemented does make a lot of economic sense as it has worked well for Nigeria and her citizens in the telecommunications sector. However, honesty of purpose demands that the Federal Government should have employed robust engagement with the people to get its position across when what is involved is taking tough decisions that would affect their 'welfare and security' which as the Constitution says, is the primary responsibility of government. The argument of promoters of fuel subsidy removal that the administration of President Goodluck Jonathan should be tough in implementing his policy of deregulation of the downstream sector of the petroleum industry without regard to populist sentiments should be disregarded as misleading. "Economic policies," notes the Nobel Prize Winner in Economics, Joseph Stiglitz "are not neutral, but ideological - and populist resistance to them is a rational response," (Nwosu, 2012).

Before yanking off his thinking cap after abandoning his editorial desk at the Nigerian Guardian newspapers to join the establishment, which he had spent a greater part of his journalism career years hauling constructive fires and brimstones at, Reuben Abati had in an article in the Guardian (2009) advocated the stoning of economists in official corridors for advancing outdated economic arguments to justify deregulation policy. He wrote thus:

The arguments being advanced to justify the proposed full deregulation do not make sense. All the arguments have a ring of deja vu. They are taken from the same textbooks that the economists have refused to update, the same ideas that led to the collapse of the global economy. Other countries are making a U-turn and subjecting textbook knowledge to the test of reality, Nigerian policy makers are still holding on to old paradigms. One of these days, we shall start stoning the economists in official corridors.

That was the old Reuben, the thoroughbred regular columnist in his fine journalistic elements. One wonders if the new improved Reuben, the loquacious Presidential spokesman, would still summon enough liver to stone his 'fellow economists' at the Aso Rock bedroom of power.

Nonetheless, the truth of the matter is that for decades, armchair theorists and fleeting ideologues have virtually turned this country into a huge laboratory for conducting wild economic experiments with attendant hardships on the people. Now, the people of Nigeria have in one united voice said a loud vociferous 'NO' to an economic policy, which compels them to subsidise the filthy hedonistic tastes of the tiny ruling elite class. It is a trait of accountable and responsible leadership to defer to the popular feelings of the people. Government needs to roll back its regimented fixations on the economic policy and rethink the hogwash about 'no going back' and 'no alternative to subsidy withdrawal'. Let the Government imbibe humility from the grass and be not like the tree; let those in government bend down a little and listen to the ordinary Nigerians. The grass bends with the wind and rises when the wind blows away. Big trees are arrogant. They stand erect, resisting the wind and are broken by the force of the wind for standing in its way.

This is even more relevant in a contemporary world wherein the people power has blossomed so significantly that no sane leader can afford to ignore. The Arab World is turning upside down and inside out in a momentous revolution called Arab Spring. The streets of western world's capital cities are quaking with 'occupy movement'. Despite turning the Egypt's democratic space into a jungle filled with warring denizens, whose practised predilection for brutalization of protesters is legendary, cameras and iphones were adept at tweeting the obscene images (of female protesters stripped naked) instantly around the world. Nigerians live in a close-nit world that is interconnected. They cannot but learn the power of peaceful protests as demonstrators in Abuja, Kano, Ibadan, Benin, Kaduna, Ilorin and Lagos had shown. Although the protesters may not have succeeded in effecting regime change but they have invariably proved seminal in having planted the seeds of 
change and activated the sim pack of people power in the usually docile and agitation-indifferent Nigerian political environment.

It is not difficult to identify the source of the people power infection of the Nigerian political system as the street revolution in North Africa disgracefully ended the tyrannical regimes of former despots - Ben Ali in Tunisia, Housni Mubarak in Egypt, and Muammar Gaddafi in Libya. As indispensable as these despots thought they were to the security and progress of their nations, their people survived them without an earthquake or eclipse of the sun and new leaders have kept the torch of governance burning and blowing in the direction of the masses' interests and welfare ever since. The current Nigerian power brokers holed up in the Aso Rock sanctuary cannot afford to give the impression that they have not learnt anything from the experiences of the despots vanquished by people power in the nations aforementioned. If it has not been their earnest ambitions and honest desires to be blown away by the roiling hurricane of change sweeping across the globe, then, President Jonathan and his team should learn to respect the wishes of Nigerians and always leave an exit door for negotiations to resolve difficult political and human issues.

The second lesson is that from the fundamental agitation for immediate reversion to the old pump price of N65 per litre, the demands have been expanded to include not only concerted action against corruption in the oil industry but drastic reformatting of the entire governance's central processing unit. The big lesson is that so long as corruption continues as the country's chief industry; poverty rules the lives of 90 percent of the population and workers are miserably underpaid, so long will Nigerians continue to resist subsidy withdrawal. This underscores the imperative of enthroning good governance as a state policy. The essence of any democracy irrespective of its colour and shape, nation or region is good governance. Good governance is expected to roll back the frontiers of national poverty and create in the citizens the sense of hope. It is the major antidote to socio-political upheaval and a veritable enabler of development. A nation such as Nigeria, which seeks development, must necessarily embrace good governance as an inescapable option, Mimiko (2011).

\section{Conclusion}

The primacy of language as the exclusively and uniquely human means of communication is all about investing the homo loqueans with the faculty of speech to express and describe not only the expressible and describable but also the inexpressibility of the inexpressible and indescribability of the indescribable. Nigerians latched onto this uniquely human predisposition to voice out their opposition to the entire governance process in their country. This peculiar linguistic behaviour was examined from the theory of language, which emphasizes the centrality of language function. To this effect, the whole gamut of choices, which language makes available to its users (speakers/writers) is examined. These choices relate speakers' and writers' intentions to the concrete forms of a language. By analysing the functions of language as the basis of human communication activity, we shed more light on the 'context of situation,' which obtains "through a systematic relationship between the social environment on the one hand, and the functional organization of language on the other," (Halliday, 1985: $11)$.

From the theoretical standpoint of Halliday's systemic functional linguistics, the context examined in this paper is the oil subsidy removal, the spontaneous responses of Nigerians, and the channels of communication adopted, (Halliday, 1995). In this regard, we chose for study the placards as one of the aspects of channel of communication, which Nigerians adopted for exploiting the functional potentialities of language. By deft combination of creativity and ingenuity, the fuel subsidy protesters deployed placards in making fundamental statements about their collective demands for a total re-invention of the entire governance process in Nigeria. Specifically, they demanded immediate reversion to the old pump price of N65 per litre of PMS, concrete action against endemic corruption especially in the oil industry, and the enthronement of good governance. They equally served a clear notice of popular revolution driven by people power Nigeriana.

The implication of the foregoing is that Nigerians have finally found their collective voices long drowned in the sea of group inertia and complacency. They have, more than ever before, become resolute in challenging all the imprimaturs of instrumental leadership foisted on their country by the ruling class. And like the Tunisian revolutionaries, Nigerians seem to be saying:

The power of the revolution lies within us, with us and only and until we decide to rise up and stand our grounds for our rights; until the day when it is said of us that 'For this great humanity has said "enough" and has started to move forward.' And our march, the march of giants, cannot stop, will not stop until we have attained our true independence, for which many of us have already died, and not uselessly; we will die for our never-to-be-renounced, our only true independence.

It makes little sense to underestimate the power of the people. The "people power" revolution that removed Ferdinand Marcos from power in 1986 and the Arab Spring of 2011 that led to the fall of Abidine Ali, President of Tunisia; Hosni Mubarak, President of Egypt and Muamar Gaddafi of Libya, were all products of a commonly-shared determination by the people to get rid of their rulers that had lost touch with the realities of their modest aspirations. Nigerians may not be Filipinos (who blocked Marcos' military tanks with their bodies 
to prevent them from storming Camp Crame to kill defecting Defence Minister, Juan Ponce Enrile and Deputy Chief of Staff, Fidel Ramos). Also, they may not have in their veins the hot blood of the Arabs who protested day and night for months, braving bullets, armoured tanks and teargas without wilting. Yet, they are not oblivious of the lesson from history, which states that ideas and movements of common concern never die in the annals of history without achieving their goal.

The Nigerian people, who have borne the enormous social costs of the series of adjustments and neoliberal reforms imposed on the country, have spoken loudly and celestial wisdom demands that Mr. President listens to the resonant voices on the street. As Komalafe (2012) surmises, "Obstinacy in implementing unpopular policies is not a mark of effective leadership; it is a subversion of popular democracy. The President should avoid this anti-people road". Need we say more?

\section{References}

[1] G. Thompson, Introducing functional grammar $2^{\text {nd }}$ Edition, (London: Hodder Education, 2004).

[2] M. A. K. Halliday, Explorations in the functions of language, (London: Edward Arnold, 1973).

[3] C. Amuta, Subsidy: Teachable moments. Retrieved from: http://www.thisdaylive.com 17 January, 2012. Accessed: 18 January, 2012.

[4] O. Gabriel, The economic danger signals are here; lets act fast now. Retrieved from: http://www.vanguardngr.com 23 January, 2012. Accessed: 23 January, 2012.

[5] M. A. K. Halliday, Introduction to functional grammar, $2^{\text {nd }}$ Edition, (London: Edward Arnold, 1994).

[6] M. A. K. Halliday, Spoken and written language, (Oxford: Oxford University Press, 1985).

[7] G. Brown \& G. Yule, Discourse analysis, (Cambridge: Cambridge University Press, 1983).

[8] V. Mathesius, From comparative word order studies. Casopis pro Moderni Filologii 28, 1942).

[9] M. A. K. Halliday, Linguistics and the teaching of English, in. J. N. Britton (Ed.), Talking and writing: A handbook for English teachers, (London: Methuen, 1967).

[10] V. Oluwasegun \& D. Anofi, We'll compel the authorities to implement subsidy probe report. Retrieved from http://www.thenationonlineng.net 20 Febraury, 2012. Accessed: 18 March, 2012.

[11] C. Umoren, C. (2012). We have lost confidence in FG. www.thisdaylive.com 05 January. Accessed: 05 January, 2012.

[12] T. Akowe, Jonathan has declared war on Nigerians, says civil society. Retrieved from: http://www.thenationonlineng.net 09 January, 2012, Accessed: 10 January, 2012.

[13] A. Ehikioya, Doctors vow to hit the street. http://www.thenationonlineng.net 09 January. Accessed: 10 January, 2012.

[14] D. Fafowora, Public service and cost of governance. Retrieved from: http://www.thenationonlineng.net 15 September, 2011. Accessed: 17 January, 2012.

[15] Nigerian Guardian editorial, Removal of oil subsidy (3). Retrieved from: http://www.ngrguardiannews.com Wednesday, 11 January, 2012. Accessed: 12 January, 2012.

[16] L. Salaudeen, Jonathan's government by task forces, committees. Retrieved from: http://www.thenationonlineng.net 13 March, 2012. Accessed: 18 March, 2012.

[17] Nigerian Guardian editorial, Fuel subsidy: a question of leadership. Retrieved from: http://www.ngrguardiannews.com Monday, 23 January, 2012. Accessed: 24 January, 2012.

[18] O. Mimiko, People Power, Good Governance and the Future of Democracy in Nigeria. Being Keynote Address Delivered at the Public Presentation of the 'Nigeria Golden Book' by The Sun Publishing Ltd, on 27th September, 2011, at The Shehu Yar'adua Centre, Abuja. Retrieved from: http://www.thenigerianvoice.com Accessed: 20 January, 2012.

[19] C. Amuta, Subsidy: Teachable moments. Retrieved from: http://www.thisdaylive.com 17 January, 2012. Accessed: 18 January, 2012.

[20] I. Nwosu, Subsidy removal: I'm ready for mass revolt -Jonathan Retrieved from: http://www.sunnewsonline.com Sunday, 11 December, 2011. Accessed: 12 December, 2011.

[21] O. Mimiko, People Power, Good Governance and the Future of Democracy in Nigeria. Being Keynote Address Delivered at the Public Presentation of the 'Nigeria Golden Book' by The Sun Publishing Ltd, on 27th September, 2011, at The Shehu Yar'adua Centre, Abuja. Retrieved from: http://www.thenigerianvoice.com Accessed: 20 January, 2012.

[22] M. A. K. Halliday, Spoken and written language, (Oxford: Oxford University Press, 1985).

[23] M. A. K. Halliday, Learning how to mean: Explorations in the development of language, (London: Edward Arnold, 1975),

[24] K. Komolafe, It's a virtue to listen to the people. Retrieved from: http://www.thisdaylive.com 11 January, 2012. Accessed: 11 January, 2012. 


\section{Appendix}

A sample of the placards
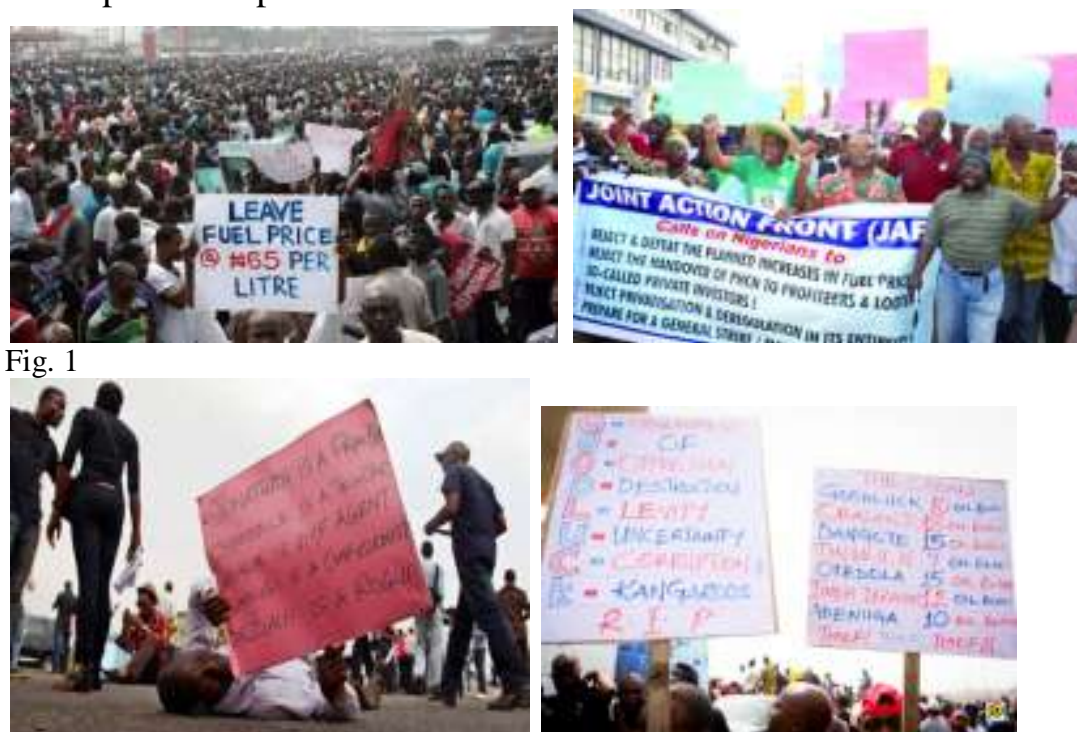

Fig. 2
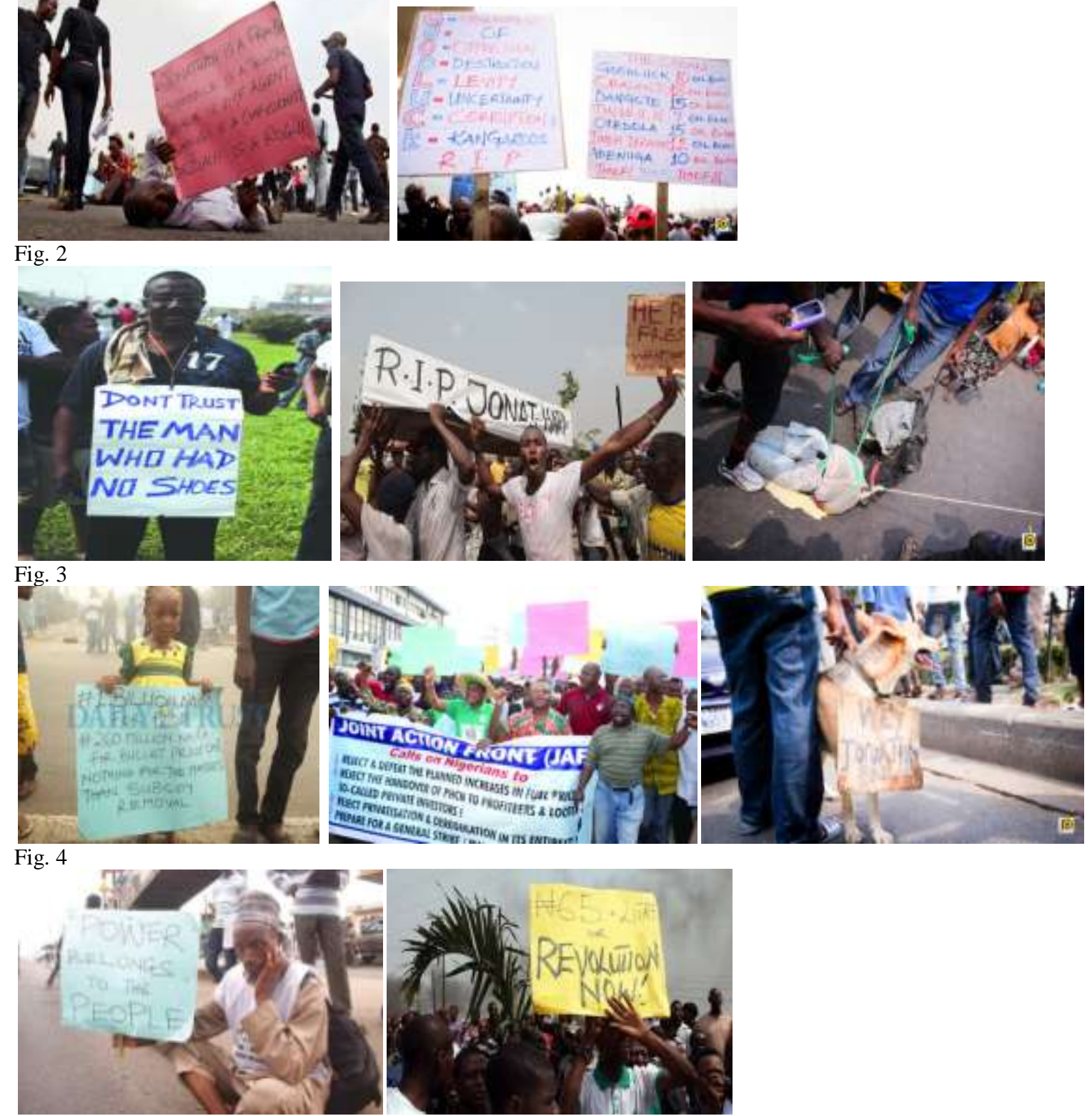

Fig. 5 